\title{
Phytoprotection
}

\section{Field comparison of sterol-biosynthesis-inhibiting fungicides used alone and in combination with protectant fungicides for apple scab control}

\section{J. Warner}

Volume 71, numéro 1, 1990

URI : https://id.erudit.org/iderudit/705976ar

DOI : https://doi.org/10.7202/705976ar

Aller au sommaire du numéro

Éditeur(s)

Société de protection des plantes du Québec (SPPQ)l

ISSN

0031-9511 (imprimé)

1710-1603 (numérique)

Découvrir la revue

Citer cet article

Warner, J. (1990). Field comparison of sterol-biosynthesis-inhibiting fungicides used alone and in combination with protectant fungicides for apple scab control. Phytoprotection, 71(1), 1-8. https://doi.org/10.7202/705976ar
Résumé de l'article

Nous avons évalué plusieurs fongicides inhibiteurs de la biosynthèse des stérols (IBS) seuls ou combinés avec des matériaux de protection à large spectre d'action lors d'essais au champ contre le Venturia inaequalis. Lorsqu'utilisés dans un programme de vaporisation de 10 jours, les fongicides IBS, utilisés seuls ou en combinaison, ont permis une meilleure répression de la tavelure de la pomme, comparativement au matériel de protection utilisé seul. Avec le bitertanol, le diniconazole et le penconazole, le mélange a aussi procuré une meilleure répression de la tavelure que lorsque les fongicides IBS étaient utilisés seuls. Cependant, avec le flusilazole et le myclobutanil, aucune amélioration de la répression de la tavelure ne s'est produite comparativement au fongicide IBS utilisé seul. Nous avons observé le roussissement des fruits après une application post-floraison d'hexaconazole et des effets régulateurs de croissance sur le feuillage suite à l'utilisation de cyproconazole et d'hexaconazole. Nous discutons de l'utilisation des fongicides IBS en mélange afin d'éviter le développement de résistance par le champignon.
Ce document est protégé par la loi sur le droit d'auteur. L'utilisation des services d’Érudit (y compris la reproduction) est assujettie à sa politique d'utilisation que vous pouvez consulter en ligne.

https://apropos.erudit.org/fr/usagers/politique-dutilisation/ 


\title{
Field comparison of sterol-biosynthesis-inhibiting fungicides used alone and in combination with protectant fungicides for apple scab control
}

\author{
J. Warner \\ Agriculture Canada, Research Branch, Smithfield Experimental Farm, \\ P.O. Box 340, Trenton, Ontario, Canada K8V 5R5
}

(Received 1989-03-29; accepted 1989-09-08)

\begin{abstract}
Several sterol-biosynthesis-inhibiting (SBI) fungicides were tested alone and in combination with a broadspectrum protectant material in field trials for control of Venturia inaequalis. When used in a 10-day spray schedule, SBI fungicides, whether used alone or in a mixture, provided improved scab control as compared to the protectant material used alone. With bitertanol, diniconazole, and penconazole, the mixture also provided better scab control than when the SBI fungicide was used alone. However, with flusilazole and myclobutanil, no improvement in disease control occurred with the mixture as compared to the SBI fungicide alone. Fruit russeting was observed after a post-bloom application of hexaconazole and growth-regulating effects on the foliage were observed following cyproconazole and hexaconazole use. The use of SBI fungicides in mixtures to avoid or delay the development of fungus resistance is discussed.
\end{abstract}

Warner, J. 1990. Field comparison of sterol-biosynthesis-inhibiting fungicides used alone and in combination with protectant fungicides for apple scab control. PHYTOPROTECTION 71 : 1-8.

Nous avons évalué plusieurs fongicides inhibiteurs de la biosynthèse des stérols (IBS) seuls ou combinés avec des matériaux de protection à large spectre d'action lors d'essais au champ contre le Venturia inaequalis. Lorsqu'utilisés dans un programme de vaporisation de 10 jours, les fongicides IBS, utilisés seuls ou en combinaison, ont permis une meilleure répression de la tavelure de la pomme, comparativement au matériel de protection utilisé seul. Avec le bitertanol, le diniconazole et le penconazole, le mélange a aussi procuré une meilleure répression de la tavelure que lorsque les fongicides IBS étaient utilisés seuls. Cependant, avec le flusilazole et le myclobutanil, aucune amélioration de la répression de la tavelure ne s'est produite comparativement au fongicide IBS utilisé seul. Nous avons observé le roussissement des fruits après une application post-floraison d'hexaconazole et des effets régulateurs de croissance sur le feuillage suite à l'utilisation de cyproconazole et d'hexaconazole. Nous discutons de l'utilisation des fongicides IBS en mélange afin d'éviter le développement de résistance par le champignon.

\section{Introduction}

Sterol-biosynthesis-inhibiting (SBI) fungicides have been under investigation for the control of apple scab, caused by Venturia inaequalis (Cke.) Wint., for many years. SBI fungicides are generally regarded as having good to excellent post-infection qualities (Ellis et al. 1984; Gupta and Kumar 1985; Kelley and Jones 1981; O'Leary and Sutton 1986; O'Leary et al. 1987; Schwabe and Jones 1983; Schwabe et al. 1984; Szkolnik 1981) but poorer protectant control (O'Leary et al. 1987; Schwabe and Jones 1983; Schwabe et al. 1984; Szkolnik 1981) than conventional protectant fungicides. When used in a 7- to 10-day spray program, SBI fungicides were highly effective in controlling apple scab (Biggs and Warner 1987; O'Leary et al. 1987; Yoder 1982; Yoder and Hickey 1981) due

$\overline{0031-9511 / 90} \$ 1.00+.10$ to a combination of their eradicant and protectant capabilities. Schwabe and Jones (1983) suggested the use of fungicide mixtures containing a SBI fungicide plus a conventional protectant fungicide to extend the application interval with mixtures and to reduce the chance for fungal resistance development. O'Leary et al. (1987) reported that flusilazole $(9.4$ to 14.0 $\mu \mathrm{g} / \mathrm{mL}$ ) and pyrifenox (37.5 to 75.0 $\mu \mathrm{g} / \mathrm{mL}$ ) were highly effective in controlling apple scab when applied on a 7-day schedule but control was dramatically reduced when the spray interval was extended to 14 days. The addition of a conventional protectant fungicide at near full recommended rates gave good control on a 14-day schedule.

SBI fungicides belong to a group of fungicides with a single site mode of action (Koller and Scheinpflug 1987). While Stanis and Jones (1985) suggested, from laboratory observations, that reduced sensitivity of $V$. inaequalis to SBI fungicides is controlled by a single gene, field observations 
by Hildebrand et al. (1989) are typical of multiple gene resistance. These factors indicate a high risk of developing fungus resistance. It is important to investigate programs using SBI fungicides which will prevent or delay the development of fungus resistance without decreasing their effectiveness in a control program.

This paper presents the results of four years of field trials to determine the effect of SBI fungicides used alone and in combination with broad-spectrum protectants on the disease incidence on apple leaves and fruits. The use of fungicide mixtures as a means to delay the development of fungus resistance is also discussed.

\section{Materials and methods}

Fungicides. The materials used in these studies were captan (Captan-50 WP), CGA 453-250 EC, cyproconazole (San 619F-10 WG), diniconazole (Spotless-25 WP), flusilazole (Nustar-20 DF), hexaconazole (ICIA 0523-5 SC), mancozeb (Dithane-75 DG, Manzate 200-80 WP), myclobutanil (Systhane-60 DF) and penconazole (Topas-100 EC). Premix combinations used were cyproconazole + mancozeb (SAN 683F-63 WG), penconazole + mancozeb (Topas MZ-61 WP) and pyrifenox + mancozeb (ACR 3815-70 WP). Tank mix combinations used were bitertanol (Baycor-50 WP) + captan, CGA 453 + mancozeb, diniconazole + captan, flusilazole + mancozeb, hexaconazole + mancozeb, myclobutanil + mancozeb and triflumizole (Procure-50 WP) + captan. Concentrations of fungicides and spray dates are given in the appropriate tables.

Field trials. All experiments were conducted at the Smithfield Experimental Farm, Trenton, Ontario. The apple trees (Malus domestica Borkh.) cv. McIntosh were planted in 1971 on M.9 or M.26 rootstock and spaced at $1.5 \mathrm{~m} \times 3.0 \mathrm{~m}$ with $3.0 \mathrm{~m}$ between plots. The 1988 trial was carried out on apple trees cv. McIntosh planted in 1971 on MM.106 rootstock spaced at $3.0 \mathrm{~m} \times 5.0 \mathrm{~m}$. All treatments were replicated three times using a randomized complete block design where each plot had three trees. Three or more guard trees were left between plots to minimize spray drift. Fungicides were sprayed with a hydraulic handgun attached to a Rittenhouse plot sprayer operated at $2700 \mathrm{kPa}$ until runoff was observed. Approximately $3000 \mathrm{~L}$ spray volume per ha was applied.

In all years, data on temperature and leaf wetness duration were recorded using a Crop Tech Orchard Monitor (Crop Technologies Inc., Bloomingdale, Ont.). Infection periods were determined using Mills' criteria (Mills 1944).

In each year, the first spray was applied as soon as possible (48-96 h) after the first apple scab infection period. Except for one period in May 1987, subsequent sprays were applied at approximately 10-day intervals until late June or early July each year. In May 1987, the interval between sprays was 26 days.

Disease incidence was determined in midseason each year by examining all leaves and fruits of 20 clusters and all leaves of 10 terminal shoots per plot. Preharvest assessments were carried out in August or early September by examining all leaves of 20 terminal shoots, and 100 fruits per plot. In 1988, additional data on fruit russeting was collected at harvest. Data were expressed as percentage of leaves or fruit with scab or russeting. The data were subjected to an analysis of variance and, when a significant F-test was obtained $(P \leq 0.05)$, means were separated using Duncan's multiple range test $(P=0.05)$. All percentage data were transformed to $\arcsin \sqrt{\mathrm{X}}$ prior to analysis (Steel and Torrie 1980). Retransformed data showing actual percentages are presented in the tables.

Interactions in the response to fungicide mixtures were also examined. The following formula proposed by Gowing (1960) when studying herbicide mixtures was used to determine expected responses:

$$
E=X+Y[(100-X) / 100]
$$

where $\mathrm{X}$ is the percentage of control from one fungicide, $\mathrm{Y}$ is the percentage of control from the second fungicide and $\mathrm{E}$ is the expected percentage of control from the combination. The combination is considered synergistic when the observed response is greater than the expected value; it is antagonistic when the observed response is 
less than the expected value but the combination is considered additive when the observed and expected responses are equal (Colby 1967).

\section{Results}

Between 4 May and 30 July 1985, disease incidence was heavy with 14 primary and secondary apple scab infection periods. By harvest, $100 \%$ of the terminal leaves and $97 \%$ of the fruit were infected with scab in the unsprayed control treatment (Table 1). All fungicide treatments significantly $(P \leq 0.05)$ reduced the incidence of apple scab on both the fruit and foliage as compared to the untreated control. The treatment penconazole + mancozeb provided improved scab control as compared to mancozeb alone and improved cluster leaf and preharvest terminal leaf scab control as compared to penconazole alone. Likewise, the treatment of diniconazole + captan reduced the incidence of apple scab as compared to captan alone and as compared to diniconazole alone in the preharvest fruit scab assessment. The treatments bitertanol + captan and triflumizole + captan reduced scab as compared to captan alone. However, bitertanol and triflumizole alone were not used in this study. There was no significant difference $(P>0.05)$ in the incidence of scab between the two rates of bitertanol or diniconazole when used in combination with captan.

In 1986, combination treatments of bitertanol + captan and diniconazole + captan were used, but at lower rates of the SBI fungicide than used in 1985 (Table 2). Weather conditions were very favourable for apple scab development and 18 primary and secondary infection periods occurred between 20 April and 1 August 1986. Disease incidence at preharvest on the terminal leaves provided the best indication of scab control during 1986. The treatments penconazole + mancozeb and either bitertanol + captan or diniconazole + captan reduced preharvest terminal leaf scab as compared to mancozeb or captan alone, respectively. Penconazole + mancozeb also reduced the incidence of preharvest fruit scab as compared to mancozeb alone. The highest rate of bitertanol (7.5 g a.i./ $100 \mathrm{~L})$ or diniconazole $(1.5 \mathrm{~g}$ a.i. / $100 \mathrm{~L})$ in combination with captan provided better preharvest leaf and fruit scab control than did the lower rates. However, the level of significance differed depending on the comparison being made.

In 1987, the first fungicide spray was applied 29 April. No additional sprays were applied until 25 May. During this time there were three infection periods, 27-29 April,

Table 1. Influence of sterol-biosynthesis-inhibiting fungicides on the incidence of Venturia inaequalis on apple leaves and fruits in 1985

\begin{tabular}{|c|c|c|c|c|c|c|}
\hline \multirow[b]{3}{*}{ Treatment } & \multirow[b]{3}{*}{$\begin{array}{c}\text { Dose } \\
(\mathrm{g} \text { a.i. } / 100 \mathrm{~L})\end{array}$} & \multicolumn{5}{|c|}{ Disease incidence (\%) } \\
\hline & & \multicolumn{3}{|c|}{24 June } & \multicolumn{2}{|c|}{$\begin{array}{c}\text { Preharvest } \\
3 \text { to } 13 \text { September }\end{array}$} \\
\hline & & $\begin{array}{c}\text { Terminal } \\
\text { leaves }\end{array}$ & $\begin{array}{l}\text { Cluster } \\
\text { leaves }\end{array}$ & Fruit & $\begin{array}{l}\text { Terminal } \\
\text { leaves }\end{array}$ & Fruit \\
\hline Control & & $36.7 \mathrm{a}^{\S}$ & $81.7 \mathrm{a}$ & $88.1 \mathrm{a}$ & 100 a & $96.7 \mathrm{a}$ \\
\hline Mancozeb & 160.0 & $18.3 \mathrm{~b}$ & $25.6 \mathrm{~b}$ & $2.4 \mathrm{~cd}$ & $16.2 \mathrm{c}$ & $7.7 \mathrm{bcd}$ \\
\hline Mancozeb & 80.0 & $18.3 \mathrm{~b}$ & $33.9 \mathrm{~b}$ & $12.7 \mathrm{~b}$ & $21.9 \mathrm{~b}$ & $11.7 \mathrm{bc}$ \\
\hline Penconazole & 2.2 & 4.3 cde & $20.9 \mathrm{~b}$ & $3.8 \mathrm{~cd}$ & $6.9 \mathrm{~d}$ & $2.7 \mathrm{cde}$ \\
\hline Penconazole + mancozeb & $2.1+80.0$ & $2.7 \mathrm{de}$ & $9.7 \mathrm{c}$ & $0.7 \mathrm{~d}$ & $3.6 \mathrm{ef}$ & $0 \quad \mathrm{e}$ \\
\hline Captan & 67.0 & $9.4 \mathrm{c}$ & $23.0 \mathrm{~b}$ & $8.2 \mathrm{bc}$ & $14.4 \mathrm{c}$ & $10.0 \mathrm{bc}$ \\
\hline Bitertanol + captan & $3.7+67.0$ & $5.4 \mathrm{~cd}$ & $9.0 \mathrm{c}$ & $0 \mathrm{~d}$ & $3.0 \mathrm{ef}$ & $2.0 \mathrm{de}$ \\
\hline Bitertanol + captan & $7.5+67.0$ & $1.7 \mathrm{de}$ & $7.1 \mathrm{c}$ & $0.9 \mathrm{~d}$ & $2.3 \mathrm{e}$ & $1.3 \mathrm{de}$ \\
\hline Diniconazole + captan & $1.5+67.0$ & $1.4 \mathrm{de}$ & $5.6 \mathrm{c}$ & $2.8 \mathrm{bcd}$ & $5.2 \mathrm{de}$ & $0.3 \mathrm{de}$ \\
\hline Diniconazole + captan & $3.0+67.0$ & $1.2 \mathrm{de}$ & $4.0 \mathrm{c}$ & & $5.7 \mathrm{de}$ & $0.7 \mathrm{de}$ \\
\hline Diniconazole & 3.0 & $2.7 \mathrm{de}$ & $7.2 \mathrm{c}$ & $5.5 \mathrm{bcd}$ & $4.8 \mathrm{def}$ & $17.7 \mathrm{~b}$ \\
\hline Triflumizole + captan & $8.3+67.0$ & $0.8 \mathrm{e}$ & $5.1 \mathrm{c}$ & $0 \mathrm{~d}$ & 3.0 ef & $0 \mathrm{e}$ \\
\hline
\end{tabular}

$\S$ Means followed by the same letter within each colum are not significantly different using Duncan's multiple range test $(P>0.05)$. The data were analysed following arcsin transformation but are presented as retransformed data. Treatments were applied on 6, 16, 28 May, 7, 17, 27 June, and 11 July. 
Table 2. Influence of sterol-biosynthesis-inhibiting fungicides on the incidence of Venturia inaequalis on apple leaves and fruits in 1986

\begin{tabular}{|c|c|c|c|c|c|c|}
\hline \multirow[b]{3}{*}{ Treatment } & \multirow[b]{3}{*}{$\begin{array}{c}\text { Dose } \\
(\mathrm{g} \mathrm{a.i.} / 100 \mathrm{~L})\end{array}$} & \multicolumn{5}{|c|}{ Disease incidence $(\%)$} \\
\hline & & \multicolumn{3}{|c|}{17 June } & \multicolumn{2}{|c|}{$\begin{array}{c}\text { Preharvest } \\
3 \text { to } 5 \text { September }\end{array}$} \\
\hline & & $\begin{array}{l}\text { Terminal } \\
\text { leaves }\end{array}$ & $\begin{array}{l}\text { Cluster } \\
\text { leaves }\end{array}$ & Fruit & $\begin{array}{c}\text { Terminal } \\
\text { leaves }\end{array}$ & Fruit \\
\hline Control & & $15.3 \mathrm{a}^{\S}$ & $11.5 \mathrm{a}$ & $41.6 \mathrm{a}$ & $99.3 \mathrm{a}$ & $81.5 \mathrm{a}$ \\
\hline Mancozeb & 80.0 & $8.8 \mathrm{ab}$ & $0.3 \mathrm{~b}$ & & $29.5 \mathrm{c}$ & $3.0 \mathrm{bc}$ \\
\hline Penconazole + mancozeb & $2.1+80.0$ & $4.6 \mathrm{bc}$ & $0.9 \mathrm{~b}$ & & $15.2 \mathrm{~d}$ & $0.6 \mathrm{~d}$ \\
\hline Captan & 67.0 & $6.9 \mathrm{abc}$ & $0 \quad \mathrm{~b}$ & & $48.8 \mathrm{~b}$ & $2.6 \mathrm{bc}$ \\
\hline Bitertanol + captan & $1.9+67.0$ & $5.5 \mathrm{bc}$ & 0 & $1.3 \mathrm{~b}$ & $13.8 \mathrm{~d}$ & $5.1 \mathrm{~b}$ \\
\hline Bitertanol + captan & $3.8+67.0$ & $4.4 \mathrm{bc}$ & & $2.3 \mathrm{~b}$ & $7.4 \mathrm{~d}$ & $4.0 \mathrm{bc}$ \\
\hline Bitertanol + captan & $7.5+67.0$ & $3.5 \mathrm{bcd}$ & $0.3 \mathrm{~b}$ & $0.7 \mathrm{~b}$ & $1.6 \mathrm{e}$ & $1.1 \mathrm{~cd}$ \\
\hline Diniconazole + captan & $0.5+67.0$ & $0.3 \mathrm{~d}$ & & & $17.8 \mathrm{~cd}$ & $3.3 \mathrm{bc}$ \\
\hline Diniconazole + captan & $1.0+67.0$ & $4.6 \mathrm{bc}$ & $0.3 \mathrm{~b}$ & $2.3 \mathrm{~b}$ & $14.2 \mathrm{~d}$ & $4.7 \mathrm{~b}$ \\
\hline Diniconazole + captan & $1.5+67.0$ & $1.9 \mathrm{~cd}$ & $0 \quad b$ & $0 \quad b$ & $9.3 \mathrm{~d}$ & $0.8 \mathrm{~cd}$ \\
\hline
\end{tabular}

$\S$ Means followed by the same letter within each column are not significantly different using Duncan's multiple range test $(P>0.05)$. The data were analysed following arcsin transformation but are presented as retransformed data. Treatments were applied on 22 April, 2, 16, 26 May, 5, 16, 26 June, and 8 July.

14-15 May and 22-23 May. Eleven additional infection periods occurred between 26 May and 31 July 1987. Generally, scab incidence was higher during the mid-season assessment in 1987 (Table 3) as compared to the other years (Tables 1, 2, 4, and 5). Pre-harvest assessments indicated that $100 \%$ of the fruits and $98 \%$ of the terminal leaves were infected with scab in the unsprayed control plots in 1987 (Table 3). The mancozeb treatment significantly $(P \leq 0.05)$ reduced disease incidence as compared to the control treatment. All SBI fungicides, either used alone or in combination with mancozeb, further reduced disease incidence. Flusilazole or myclobutanil used alone were as effective in controlling scab as were the combination treatments of flusilazole + mancozeb or myclobutanil + mancozeb, respectively. The high rate of flusilazole $(1.2 \mathrm{~g}$ a.i./100 L) reduced disease incidence as compared to the lower rate $(0.6 \mathrm{~g}$ a.i. $/ 100 \mathrm{~L})$, but the effect was significant $(P \leq 0.05)$ only for terminal leaf scab on 19 August.

Table 3. Influence of sterol-biosynthesis-inhibiting fungicides on the incidence of Venturia inaequalis on apple leaves and fruits in 1987

\begin{tabular}{|c|c|c|c|c|c|c|}
\hline \multirow[b]{3}{*}{ Treatment } & \multirow[b]{3}{*}{$\begin{array}{c}\text { Dose } \\
(\mathrm{g} \mathrm{a.i.} / 100 \mathrm{~L})\end{array}$} & \multicolumn{5}{|c|}{ Disease incidence $(\%)$} \\
\hline & & \multicolumn{3}{|c|}{16 June } & \multirow{2}{*}{$\begin{array}{c}19 \text { August } \\
\begin{array}{c}\text { Terminal } \\
\text { leaves }\end{array} \\
\end{array}$} & \multirow{2}{*}{$\begin{array}{c}2 \text { September } \\
\text { Fruit }\end{array}$} \\
\hline & & $\begin{array}{c}\text { Terminal } \\
\text { leaves }\end{array}$ & $\begin{array}{l}\text { Cluster } \\
\text { leaves }\end{array}$ & Fruit & & \\
\hline Control & & $51.3 \mathrm{a}^{\S}$ & $92.8 \mathrm{a}$ & $90.4 \mathrm{a}$ & $98.4 \mathrm{a}$ & $100 \mathrm{a}$ \\
\hline Mancozeb & 80.0 & $28.6 \mathrm{~b}$ & $68.1 \mathrm{~b}$ & $31.6 \mathrm{~b}$ & $60.8 \mathrm{~b}$ & $45.3 \mathrm{~b}$ \\
\hline Penconazole + mancozeb & $2.1+80.0$ & $13.0 \mathrm{c}$ & $61.9 \mathrm{bc}$ & $9.0 \mathrm{bcd}$ & $31.7 \mathrm{c}$ & $2.7 \mathrm{~cd}$ \\
\hline Flusilazole & 1.2 & $0.8 \mathrm{~d}$ & $8.7 \mathrm{e}$ & $0 \mathrm{~d}$ & $6.4 \mathrm{f}$ & \\
\hline Flusilazole & 0.6 & $4.9 \mathrm{~cd}$ & $16.8 \mathrm{de}$ & $4.7 \mathrm{~cd}$ & $19.5 \mathrm{~d}$ & $2.3 \mathrm{~cd}$ \\
\hline Flusilazole + mancozeb & $0.6+80.0$ & $11.8 \mathrm{c}$ & $45.7 \mathrm{c}$ & $2.6 \mathrm{~cd}$ & $14.0 \mathrm{de}$ & $2.0 \mathrm{~cd}$ \\
\hline Myclobutanil & 3.0 & $6.1 \mathrm{~cd}$ & $26.2 \mathrm{~d}$ & $18.3 \mathrm{bcd}$ & $11.0 \mathrm{ef}$ & $5.0 \mathrm{~cd}$ \\
\hline Myclobutanil + mancozeb & $3.0+80.0$ & $4.9 \mathrm{~cd}$ & $48.0 \mathrm{c}$ & $16.9 \mathrm{bc}$ & 7.8 ef & $2.0 \mathrm{~cd}$ \\
\hline Hexaconazole + mancozeb & $0.9,0.6^{\dagger}+80.0$ & $6.0 \mathrm{~cd}$ & $15.2 \mathrm{de}$ & $18.7 \mathrm{bc}$ & $15.4 \mathrm{de}$ & $6.7 \mathrm{c}$ \\
\hline Pyrifenox + mancozeb & $3.9+80.0$ & $4.3 \mathrm{~cd}$ & $7.9 \mathrm{e}$ & $2.3 \mathrm{~cd}$ & 8.8 ef & $1.0 \mathrm{~cd}$ \\
\hline
\end{tabular}

$\S$ Means followed by the same letter within each column are not significantly different using Duncan's multiple range test $(P>0.05)$. The data were analysed following arcsin transformation but are presented as retransformed data. Treatments were applied on 29 April, 25 May, 4, 15, 25 June, and 6 July.

$\dagger$ The higher rate was used in the first spray only and was not mixed with mancozeb. 
In 1988,12 primary and secondary infection periods occurred between 28 April and 31 July. Disease incidence was lower in 1988 than in previous years. As in 1987, the mancozeb treatment significantly $(P \leq 0.05)$ reduced disease incidence as compared to the control treatment, and all SBI fungicides either used alone or in combination with mancozeb further reduced disease incidence (Table 4). Flusilazole or myclobutanil were as effective in controlling scab as were the combination treatments flusilazole + mancozeb and myclobutanil + mancozeb, respectively. In 1988, the higher rate of flusilazole did not improve scab control as compared to the lower rate.

In the second 1988 trial, the SBI fungicides pencanozole, CGA 453, cyproconazole, hexaconazole and pyrifenox used alone or in combination with mancozeb significantly $(P \leq 0.05)$ reduced scab infection on the terminal leaves as compared to mancozeb alone (Table 5). However, there was no significant $(P>0.05)$ difference in fruit or cluster leaf scab between the SBI fungicides and mancozeb. There were no significant $(P>0.05)$ differences in scab control on leaves or fruit between CGA 453, cyproconazole and hexaconazole when used alone or in combination with mancozeb. Fruit russeting was observed at harvest on the hexaconazole and hexaconazole + mancozeb treatments, (51 and $17 \%$, respectively). The control and mancozeb treatments had 1 and $0 \%$ of the fruits russeted, respectively. Five to seven percent fruit russeting was observed on fruits from the other treatments. Leaves from the cyproconazole, cyproconazole + mancozeb and hexaconazole treatments had a darker green colour during June as compared to leaves from other treatments.

The observed percentage of disease control using the mixtures did not differ more than $5 \%$ and usually less than $2 \%$ from that expected using the Gowing (1960) formula (Table 6). Exceptions occurred during the June 1987 assessment when the observed scab control from the mixtures was usually less than expected. However, these observations may not truly reflect the mixtures performance since a 26-day interval occurred between sprays during May 1987.

\section{Discussion}

The results reported herein show that the addition of a low rate of SBI fungicide to a broad-spectrum protectant generally improves disease control as compared to the protectant used alone. When a SBI fungicide was mixed with a broad-spectrum protectant such as captan or mancozeb, an additive effect was usually obtained. The data for 1987 and 1988 showed that at the rates tested, flusilazole and myclobutanil used alone were as effective in controlling scab as when used in combination with mancozeb, respectively. O'Leary et al. (1987) reported improved control of apple scab when using mixtures of flusilazole + mancozeb or pyrifenox + metiram on a 14-day schedule as compared to the SBI fungicide used alone. They used higher rates of the protectant as compared to the rates used in

Table 4. Influence of sterol-biosynthesis-inhibiting fungicides on the incidence of Venturia inaequalis on apple leaves and fruits in 1988

\begin{tabular}{|c|c|c|c|c|c|c|}
\hline \multirow[b]{3}{*}{ Treatment } & \multirow[b]{3}{*}{$\begin{array}{c}\text { Dose } \\
(\mathrm{g} \text { a.i. } / 100 \mathrm{~L})\end{array}$} & \multicolumn{5}{|c|}{ Disease incidence (\%) } \\
\hline & & \multicolumn{3}{|c|}{12 July } & \multicolumn{2}{|c|}{23 August } \\
\hline & & $\begin{array}{c}\text { Terminal } \\
\text { leaves }\end{array}$ & $\begin{array}{l}\text { Cluster } \\
\text { leaves }\end{array}$ & Fruit & $\begin{array}{c}\text { Terminal } \\
\text { leaves }\end{array}$ & Fruit \\
\hline Control & & $31.0 \mathrm{a}^{\S}$ & $37.2 \mathrm{a}$ & $16.2 \mathrm{a}$ & $24.1 \mathrm{a}$ & $54.7 \mathrm{a}$ \\
\hline Mancozeb & 80.0 & $12.2 \mathrm{~b}$ & $4.0 \mathrm{~b}$ & & $12.1 \mathrm{~b}$ & $2.3 \mathrm{~b}$ \\
\hline Flusilazole & 1.2 & $0.2 \mathrm{c}$ & $0 \mathrm{c}$ & $0 \mathrm{~b}$ & $0.3 \mathrm{c}$ & $0 \quad \mathrm{c}$ \\
\hline Flusilazole & 0.6 & $1.3 \mathrm{c}$ & $1.0 \mathrm{c}$ & $2.4 \mathrm{~b}$ & $1.6 \mathrm{c}$ & $1.3 \mathrm{bc}$ \\
\hline Flusilazole + mancozeb & $0.6+80.0$ & $1.5 \mathrm{c}$ & $0 \mathrm{c}$ & $0 \mathrm{~b}$ & $1.2 \mathrm{c}$ & $0.3 \mathrm{c}$ \\
\hline Myclobutanil & 3.0 & $0.2 \mathrm{c}$ & $0.3 \mathrm{c}$ & $3.2 \mathrm{~b}$ & $1.5 \mathrm{c}$ & $1.3 \mathrm{bc}$ \\
\hline Myclobutanil + mancozeb & $3.0+80.0$ & $0.2 \mathrm{c}$ & $0 \quad \mathrm{c}$ & $0 \quad b$ & $1.2 \mathrm{c}$ & $0 \quad c$ \\
\hline
\end{tabular}

$\S$ Means followed by the same letter within each column are not significantly different using Duncan's multiple range test $(P>0.05)$. The data were analysed following arcsin transformation but are presented as retransformed data. Treatments were applied on 2, 11, 20, 30 May and 8, 21, 30 June. 
Table 5. Influence of sterol-biosynthesis-inhibiting fungicides on the incidence of Venturia inaequalis on apple leaves and fruits in 1988

\begin{tabular}{|c|c|c|c|c|c|c|c|}
\hline \multirow[b]{3}{*}{ Treatment } & \multirow[b]{3}{*}{$\begin{array}{c}\text { Dose } \\
(\mathrm{g} \text { a.i. } / 100 \mathrm{~L})\end{array}$} & \multicolumn{5}{|c|}{ Disease incidence (\%) } & \multirow{3}{*}{$\begin{array}{c}\text { Fruit } \\
\text { russeting } \\
2 \text { September } \\
(\%)\end{array}$} \\
\hline & & \multicolumn{3}{|c|}{17 June } & \multicolumn{2}{|c|}{22 August } & \\
\hline & & $\begin{array}{c}\text { Terminal } \\
\text { leaves }\end{array}$ & $\begin{array}{l}\text { Cluster } \\
\text { leaves }\end{array}$ & Fruit & $\begin{array}{c}\text { Terminal } \\
\text { leaves }\end{array}$ & Fruit & \\
\hline Control & & $24.9 \mathrm{a} \S$ & $27.8 \mathrm{a}$ & $26.4 \mathrm{a}$ & $27.5 \mathrm{a}$ & $34.7 \mathrm{a}$ & $1.0 \mathrm{de}$ \\
\hline Mancozeb & 75.0 & $14.5 \mathrm{~b}$ & $2.4 \mathrm{~b}$ & $4.5 \mathrm{~b}$ & $14.7 \mathrm{~b}$ & $1.0 \mathrm{bc}$ & $0 \mathrm{e}$ \\
\hline Penconazole + & & & & & & & \\
\hline mancozeb & $2.1+80.0$ & $4.0 \mathrm{c}$ & $1.9 \mathrm{~b}$ & $0.8 \mathrm{~b}$ & $2.8 \mathrm{c}$ & $0.7 \mathrm{c}$ & $7.4 \mathrm{c}$ \\
\hline CGA 453 & 2.1 & $0 \mathrm{e}$ & $0.3 \mathrm{~b}$ & & $0.4 \mathrm{~cd}$ & $0 \mathrm{c}$ & $6.0 \mathrm{c}$ \\
\hline CGA $453+$ mancozeb & $2.1+75.0$ & & $0 \quad b$ & & $0 \mathrm{~d}$ & & $6.0 \mathrm{c}$ \\
\hline Cyproconazole & 1.0 & $0.2 \mathrm{e}$ & $0.7 \mathrm{~b}$ & $1.4 \mathrm{~b}$ & $0.7 \mathrm{~cd}$ & $1.3 \mathrm{bc}$ & $5.7 \mathrm{c}$ \\
\hline $\begin{array}{l}\text { Cyproconazole }+ \\
\text { mancozeb }\end{array}$ & $1.5+30.0$ & $0 \quad \mathrm{e}$ & $0 \quad b$ & 0 & $0.6 \mathrm{~cd}$ & $1.3 \mathrm{bc}$ & $4.7 \mathrm{~cd}$ \\
\hline Hexaconazole & $1.0 \dagger$ & $1.3 \mathrm{de}$ & $2.8 \mathrm{~b}$ & 0 & $0.6 \mathrm{~cd}$ & $3.7 \mathrm{~b}$ & $51.0 \mathrm{a}$ \\
\hline $\begin{array}{l}\text { Hexaconazole }+ \\
\text { mancozeb }\end{array}$ & $0.7 \dagger+75.0$ & $2.7 \mathrm{~cd}$ & $0.3 \mathrm{~b}$ & $0.7 \mathrm{~b}$ & $0.9 \mathrm{~cd}$ & $1.3 \mathrm{bc}$ & $17.0 \mathrm{~b}$ \\
\hline $\begin{array}{l}\text { Pyrifenox }+ \\
\text { mancozeb }\end{array}$ & $3.9+80.0$ & $1.8 \mathrm{~cd}$ & $1.1 \mathrm{~b}$ & $0.9 \mathrm{~b}$ & $0.5 \mathrm{~cd}$ & $0.3 \mathrm{c}$ & $7.0 \mathrm{c}$ \\
\hline
\end{tabular}

$\S$ Means followed by the same letter within each column are not significantly different using Duncan's multiple range test $(P>0.05)$. The data were analyzed following arcsin transformation but are presented as retransformed data. Treatments were applied on 2, 11, 20, 30 May, and 8, 17, 27 June.

$\dagger$ Mancozeb (160 g a.i./100 L) was used in sprays following calyx (8, 17, and 27 June).

the present study which may account for the improved activity of the mixtures as compared to the SBI fungicide alone.

In contrast to the results obtained with flusilazole and myclobutanil, the mixtures of diniconazole + captan and penconazole + mancozeb provided improved scab control in 1985 as compared to diniconazole or penconazole alone, respectively. Results from 1983 following an eradicant program with seven sprays of penconazole $(5 \mathrm{~g}$ a.i. / $100 \mathrm{~L})$ showed poor scab control $(25 \%$ fruit scab, $55 \%$ terminal leaf scab) as compared to 1 to $2 \%$ leaf and fruit scab by following a 10-spray protectant program using captan (100 g a.i./100 L) (Warner and Hay 1983). In 1984, bitertanol (500 g a.i./ha) was less effective in controlling apple scab (10 and $12 \%$ fruit and leaf scab, respectively) as compared to a mixture of bitertanol + captan $(250 \mathrm{~g}+2.25 \mathrm{~kg}$ a.i./ha) which resulted in 1 and $8 \%$ fruit and leaf scab, respectively (Warner and Hay 1984).

In 1986 with conditions favourable for apple scab development, scab control was improved with the higher rate of bitertanol and diniconazole as compared to their lower rates. In 1987, the higher rate of flusilazole improved scab control. However, no differ- ence in disease control between the two rates occurred in 1988. This was likely due to the lower disease incidence in 1988 as compared to 1987. Under high inoculum pressure, SBI fungicides are more effective than protectants (Biggs and Warner 1987). Although the effectiveness of CGA 453, cyproconazole and hexaconazole used in combination with mancozeb was no better than the SBI fungicide used alone in 1988, results may differ under higher inoculum pressure.

In the present study, a 7- to 8-spray program was used annually by following a 10-day spray interval starting immediately after the first infection period each season, representing a reduction from the normal 10- to 12-spray program with a protectant fungicide. Approximately half of the full recommended rate of the protectant fungicide was used in the mixtures. Increasing the rate of protectant fungicide in the mixture may allow the extension of the spray inverval beyond 10 days with a possible greater reduction in the number of sprays required for scab control.

There are several potential negative effects from SBI fungicides. Fruit russeting was greater in all SBI fungicide treatments in 1988 as compared to the control or man- 
cozeb treatments. Hexaconazole should only be used in pre-bloom sprays to avoid fruit russeting. Yoder and Hickey (1981) observed russeting of cv. Golden Delicious and lenticel enlargement on cv. Delicious from fenapanil and occasional mild russeting from other SBI fungicides. Growth regulating effects on the foliage similar to that observed with cyproconazole and hexaconazole has previously been reported for other SBI fungicides by Szkolnik (1981) and Kelley and Jones (1981). Low rates of SBI fungicides used in mixtures may reduce the risk of such undesirable side effects.
No SBI fungicides are presently registered for use on apples in Canada. When introduced, antiresistance strategies must consider the risk factors (Koller and Scheinpflug 1987; Stanis and Jones 1985; Staub and Sozzi 1984), as well as the advantages that SBI fungicides have to offer the grower. There is general agreement that where the resistance risk factors are high, a single fungicide should not be used exclusively in a season-long program (Jones 1981; Koller and Scheinpflug 1987; Staub and Sozzi 1984). Since two or more SBI fungicide applications in a program have

Table 6. Observed and expected control of Venturia inaequalis on apple leaves and fruits following fungicide treatments

\begin{tabular}{|c|c|c|c|c|c|}
\hline \multirow[b]{3}{*}{ Year and treatment } & \multicolumn{5}{|c|}{ Disease control (\%) } \\
\hline & \multicolumn{3}{|c|}{ Mid-season } & \multicolumn{2}{|c|}{ Preharvest } \\
\hline & $\begin{array}{c}\text { Terminal } \\
\text { leaves }\end{array}$ & $\begin{array}{l}\text { Cluster } \\
\text { leaves }\end{array}$ & Fruit & $\begin{array}{c}\text { Terminal } \\
\text { leaves }\end{array}$ & Fruit \\
\hline \multicolumn{6}{|l|}{1985} \\
\hline Mancozeb (M) & 81.7 & 66.1 & 87.3 & 78.1 & 88.3 \\
\hline Penconazole $(\mathrm{P})$ & 95.7 & 79.1 & 96.2 & 93.1 & 97.3 \\
\hline$M+P$, observed $^{s}$ & 97.3 & 90.3 & 99.3 & 96.4 & 100 \\
\hline $\mathrm{M}+\mathrm{P}$, expected $^{\dagger}$ & 99.2 & 92.9 & 99.5 & 98.5 & 99.7 \\
\hline Captan (C) & 90.6 & 77.0 & 91.8 & 85.6 & 90.0 \\
\hline Diniconazole (D) & 97.3 & 92.8 & 94.5 & 95.2 & 82.3 \\
\hline $\mathrm{C}+\mathrm{D}$, observed & 98.8 & 96.0 & 100 & 94.3 & 99.3 \\
\hline$C+D$, expected & 99.7 & 98.0 & 99.5 & 99.3 & 98.2 \\
\hline
\end{tabular}

1987

Mancozeb (M)

Flusilazole $(\mathrm{F})$

Myclobutanil (My)

$\mathrm{M}+\mathrm{F}$, observed

$\mathrm{M}+\mathrm{F}$, expected

$M+$ My, observed

$\mathbf{M}+\mathbf{M y}$, expected

1988

Mancozeb

Flusilazole

Myclobutanil

$\mathrm{M}+\mathrm{F}$, observed

$M+F$, expected

$\mathbf{M}+\mathbf{M y}$, observed

$M+M y$, expected

Mancozeb

CGA 453

$\mathrm{M}+\mathrm{CGA}$, observed

$\mathrm{M}+\mathrm{CGA}$, expected

$\begin{array}{lll}71.4 & 31.9 & 68.4 \\ 95.1 & 83.2 & 95.3 \\ 93.9 & 73.8 & 81.7 \\ 88.2 & 54.3 & 97.4 \\ 98.6 & 88.6 & 98.5 \\ 95.1 & 52.0 & 83.1 \\ 98.3 & 82.2 & 94.2\end{array}$

39.2

54.7

$80.5 \quad 97.7$

$89.0 \quad 95.0$

$86.0 \quad 98.0$

$88.1 \quad 99.0$

$92.2 \quad 98.0$

$93.3 \quad 97.7$

$\S$ Percentage of disease control observed in field trial.

$\uparrow$ Expected disease control predicted by Gowing (1960) formula. 
provided better control than a single application (Biggs and Warner 1987; Kelley and Jones 1981 ; O'Leary et al. 1987), it would be undesirable to recommend a program where a SBI fungicide and a protectant material are used alternately. Since $V$. inaequalis ascospores are released from a single pseudothecium during several wet periods, alternation of fungicides during the primary cycle does not prevent resistant strains from becoming established when an "at risk" fungicide is used in the rotation. A program using the SBI fungicide during the primary cycle and a fungicide with a different mode of action during the secondary cycle may be preferred.

Fungicide mixtures using products with different modes of action have also been suggested as a means to reduce the risk of fungal resistance development (Delp 1980; Jones 1981; Koller and Scheinpflug 1987; Scheinpflug 1988; Staub and Sozzi 1984). A mixture containing a SBI fungicide and a broad-spectrum protectant would also provide good eradicant and protectant capabilities. Reduced rates of the SBI component in the mixture would reduce the exposure of the fungus to the "at risk" fungicide while not decreasing disease control. With some SBI fungicides, notably bitertanol, diniconazole and penconazole, apple scab control was improved with the addition of a protectant material when used in a 10-day spray schedule. With flusilazole and myclobutanil, there did not appear to be any advantage in disease control when using the mixture as compared to using the SBI fungicide alone, but the mixture may offer an advantage in reducing the risk of fungus resistance development. Additional research to determine the effects of fungicide rates in mixtures and intervals between sprays has on disease control is required.

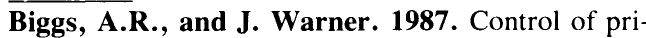
mary and secondary apple scab infections with sterol-inhibiting fungicides. Can. J. Plant Pathol. 9: 41-48.

Colby, S.R. 1967. Calculating synergistic and antagonistic responses of herbicide combinations. Weeds 15: 20-22.

Delp, C.J. 1980. Coping with resistance to plant disease control agents. Plant Dis. 64: 652-657.

Ellis, M.A., L.V. Madden, and L.L. Wilson. 1984. Evaluation of an electronic apple scab predictor for scheduling fungicides with curative activity. Plant Dis. 68: 1055-1057.
Gowing, D.P. 1960. Comments on tests of herbicide mixtures. Weeds 8: 379-391.

Gupta, G.K., and J. Kumar. 1985. Studies on the curative (after infection) and eradicant (postsymptom) activity of fungicides against apple leaf infection by Venturia inaequalis. Pesticides 19: $18-20,25$

Hildebrand, P.D., C.L. Lockhart, R.J. Newbery, and R.G. Ross. 1988. Resistance of Venturia inaequalis to bitertanol and other demethylationinhibiting fungicides. Can. J. Plant Pathol. 10: 311-316.

Jones, A.L. 1981. Fungicide resistance: Past experience with benomyl and dodine and future concerns with sterol inhibitors. Plant Dis. 65: 990-992.

Kelly, R.D., and A.L. Jones. 1981. Evaluation of two triazole fungicides for postinfection control of apple scab. Phytopathology 71: 737-742.

Koller, W., and H. Scheinpflug. 1987. Fungal resistance to sterol biosynthesis inhibitors: A new challenge. Plant Dis. 71: 1066-1074.

Mills, W.D. 1944. Efficient use of sulfur dusts and sprays during rain to control apple scab. N.Y Agric. Exp. Stn. (Ithaca) Ext. Bull. 630. 4 pp.

O'Leary, A.L., and T.B. Sutton. 1986. Effects of postinfection applications of ergosterol biosynthesis-inhibiting fungicides on lesion formation and pseudothecial development of Venturia inaequalis. Phytopathology 76: 119-124.

O'Leary, A.L., A.L. Jones, and G.R. Ehret. 1987. Application rates and spray intervals for apple scab control with flusilazole and pyrifenox. Plant Dis. $71: 623-626$.

Scheinpflug, H. 1988. Resistance management strategies for using DMI fungicides. Pages 93-94 in C.J. Delp (ed.), Fungicide resistance in North America. APS Press, St. Paul, Minn.

Schwabe, W.F.S., and A.L. Jones. 1983. Apple scab control with bitertanol as influenced by adjuvant addition. Plant Dis. 67: 1371-1373.

Schwabe, W.F.S., A.L. Jones, and J.P. Jonker. 1984. Greenhouse evaluation of the curative and protective action of sterol-inhibiting fungicides against apple scab. Phytopathology 74 : 249-252.

Stanis, V.F., and A.L. Jones. 1985. Reduced sensitivity to sterol-inhibiting fungicides in field isolates of Venturia inaequalis. Phytopathology 75 : 1098-1101.

Staub, T., and D. Sozzi. 1984. Fungicide resistance Continuing challenge. Plant Dis. 68: 1026-1031.

Steel, R.G.D., and J.H. Torrie. 1980. Principles and procedures of statistics. $2^{\text {nd }}$ ed. McGraw-Hill Inc., New York. 633 pp.

Szkolnik, M. 1981. Physical modes of action of sterol-inhibiting fungicides against apple diseases. Plant Dis. 65: 981-985.

Warner, J.T., and S.Hay. 1983. Evaluation of fungicides for apple scab control. Pestic. Res. Rep. 1983 , p. 213.

Warner, J., and S. Hay. 1984. Fungicide evaluation Pestic. Res. Rep. 1984, p. 232.

Yoder, K.S. 1982. Broad spectrum apple disease control with bitertanol. Plant Dis. 66: 580-583.

Yoder, K.S., and K.D. Hickey. 1981. Sterolinhibiting fungicides for control of certain diseases of apple in the Cumberland-Shenandoah region. Plant Dis. 65: 998-1001. 